\title{
Analysis of Ecodesign Implementation and Solutions for Packaging Waste System by Using System Dynamics Modeling
}

\author{
Alise Berzina, Institute of Energy Systems and Environment, Riga Technical University, Elina Dace, Institute of \\ Energy Systems and Environment, Riga Technical University, Gatis Bazbauers, Institute of Energy Systems and \\ Environment, Riga Technical University
}

\begin{abstract}
This paper discusses the findings of a research project which explored the packaging waste management system in Latvia. The paper focuses on identifying how the policy mechanisms can promote ecodesign implementation and material efficiency improvement and therefore reduce the rate of packaging waste accumulation in landfill. The method used for analyzing the packaging waste management policies is system dynamics modeling. The main conclusion is that the existing legislative instruments can be used to create an effective policy for ecodesign implementation but substantially higher tax rates on packaging materials and waste disposal than the existing have to be applied.
\end{abstract}

Keywords - ecodesign, packaging waste, system dynamics, waste policy.

\section{INTRODUCTION}

One of the most important environmental problems in Latvia is pollution caused by the increasing amount of waste which is annually generated and brought to landfill. Packaging waste takes constitutes a great part, about $20 \%$, of total household waste. The amount of waste which is landfilled annually has doubled since 1998 and it continues to increase slowly in spite of the fact that the regeneration (regeneration by definition includes recycling and incineration with energy recovery) rate increased from about $18 \%$ in 1998 to $41 \%$ in 2007 [1]. Therefore, it can be clearly seen that reuse, sorting and regeneration rates of the packaging waste are insufficient.

Population surveys show that almost $90 \%$ of the population is aware of the possibility of sorting the waste, but only $50 \%$ actually take action [2]. Latvia has legislative acts which set certain regeneration targets for packaging waste but the trends of waste accumulation clearly show that the existing policies cannot reduce the incremental rate of packaging waste agglomeration in landfill in order to stop the rate at least at the existing level. Latest statistical information shows that the regeneration target was not reached in the year 2007, i.e. only $41 \%$ of packaging waste was regenerated instead of $50 \%$ which was the regeneration target $[1,3]$.

To reduce the impact of packaging waste on the environment, the focus should be transferred from the solutions considering waste management at the end-of-life stage to the material or resource efficiency solutions by promotion of the ecodesign strategy - material optimization. Resource efficiency would reduce the amount of energy and materials used for packaging production therefore reducing $\mathrm{CO}_{2}$ emissions from production processes.

The system dynamics model of the "base" scenario is created and shows the projections up to 2030 if the existing policy is implemented. To simulate the impact of the ecodesign implementation policy on the packaging system as a whole, the "eco" scenario was created. Political instruments are introduced to make improvements in the whole packaging turnover system and to solve the problem related to the increase of packaging per product unit.

The "eco" scenario is the modified model of the "base" scenario with higher rates of natural resource tax (NRT) on packaging and municipal waste disposal. Therefore, the extent to which the main policy levers, i.e. natural resource taxes, can affect generation of packaging waste in Latvia is modeled in the study.

\section{RESEARCH APPROACH AND METHODS}

The hypothesis of this study was that the policy mechanisms which are mentioned above can promote ecodesign implementation and material efficiency, and reduce the increment rate of packaging waste as a result.

The method used for analyzing the impact of policy on the packaging waste system in Latvia is system dynamics modeling. System dynamics is a modelling methodology, which permits an analyst to represent graphically and mathematically the interactions governing the dynamic behavior of complex socio-economic systems [4]. The purpose of a system dynamics intervention is to identify how structure and decision policies generate system behavior identified as problematic, so that structural and policy-oriented solutions can be identified and implemented [5]. The model was developed in the program Powersim Constructor which was created by the Norwegian company "Powersim Software AS". Simulations are made for the period from the year 1998 until the year 2030 to be able to imitate the historic data and to predict future development under various scenarios by considering interactions between different factors, as well as changing the values of the main waste management policy factors, i.e. rates of NRT.

The generation volume of packaging waste depends mainly on the following: 
a) the size of the population,

b) the amount of packaging per product unit,

c) product consumption per capita.

Estimates of the amount of used packaging in the model are based on product consumption. Studies of historical data show that the consumption of products and also the amount of packaging per product unit has a tendency to grow.

The goal of this research is to analyze what policy would be effective and could reduce the primary resource consumption for manufacturing of the packaging. Therefore, two "eco" scenarios i.e. "eco" and "eco-2" are developed, and these scenarios differ by the extent at which rates of NRT on materials used in packaging and municipal waste disposal are changed relative to the "base" scenario but the structure of the "base" scenario model is preserved.

Key indicators of the packaging system, which are analyzed in the work and are compared in the studied scenarios, are the following:

a) Amount of the generated packaging waste,

b) Proportion of the population which is sorting waste,

c) Fraction of the regenerated packaging waste,

d) Amount of landfilled waste or landfill filling extent,

e) Impact of the packaging materials on the environment.

A hypothesis which is put forward about system variables and their possible changes due to the increase of NRT rates, and which should be approved in the "eco" scenarios includes the following:

a) Quantity of the generated packaging waste will decrease,

b) Proportion of the population which is sorting the waste will increase,

c) Proportion of the regenerated waste packaging will grow,

d) Amount of the annually landfilled waste and landfill filling rate will decrease,

e) Consequently, the environmental impact of packaging materials will decrease.

It is assumed in the models that the factors which will force NRT rates to go up will increase the amount of the generated waste and growth of the extent of using up landfill capacity. Thus, the NRT rate for packaging materials has been changed in proportion to the amount of generated waste and the NRT rate for municipal waste disposal has been changed in proportion to the landfill filling ratio (the ratio of landfilled waste to the capacity of landfill) in all scenarios. In the "eco" scenario, both NRT rates are changed as follows:

1. NRT rates for packaging materials are increased by a factor of 1.5 relative to the rates in the "base" scenario starting from the year 2011 (existing legislation sets NRT rates only for the period up to 2010).

2. NRT rate for municipal waste disposal is increased by a factor of 1.5 relative to the rates in the "base" scenario starting from 2013 (the existing legislation sets NRT rates only for the period up to 2012).

Currently, the NRT rates are the following:

a) For packaging it is determined depending on the type of material, but the weighted average rate considering proportions of various materials is $0.26 \mathrm{LVL} / \mathrm{kg}$ in year 2010 [6],

b) For municipal waste disposal it is $3.00 \mathrm{LVL} / \mathrm{t}$ in year 2010 [6].

When using the above model assumptions, the NRT rate for packaging in 2030 reaches $0.42 \mathrm{LVL} / \mathrm{kg}$ in the "base" scenario, but in the "eco" scenario - the value which is by $29 \%$ higher than in the "base" scenario, i.e. $0.54 \mathrm{LVL} / \mathrm{kg}$.

The NRT rate for municipal waste disposal in 2030 reaches circa $13 \mathrm{LVL} / \mathrm{t}$ in the "base" scenario, but in the "eco" scenario - $16 \mathrm{LVL} / \mathrm{t}$.

Results of the "base" and "eco" scenarios are analyzed to determine if the pace of growth of NRT rates which are used in the model are sufficiently strong legislative instrument in order to affect the amount of annually generated and landfilled packaging waste. Therefore, results of the "base" and "eco" scenarios are compared graphically to see how the key elements change the system's behavior and whether the simulation results allow to confirm the above stated hypothesis. It is important to note that the packaging system is a complex system and the variables are interrelated and contain feedback loops, i.e. changes of NRT rates affect various factors directly or indirectly affecting further outlined key system variables which in turn, have an influence on pace of growth of the NRT rates.

\section{RESULTS}

The analysis below show and describe how the key elements of the packaging system change in the "base" and "eco" scenarios.

\section{A. Amount of the generated packaging waste}

The amounts of the packaging waste generated annually in the "base" and "eco" scenarios are shown in Figure 1.

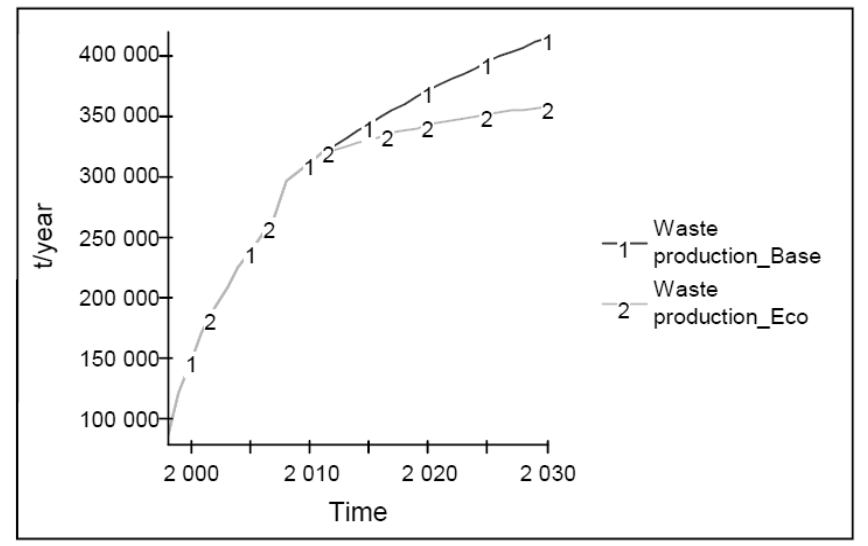

Fig. 1. Amounts of the generated packaging waste in the "base" and "eco" scenarios.

As demonstrated in the graph, during the period from 1998 to 2010 the amount of generated packaging waste is the same in both scenarios because this period reflects the historic situation in Latvia and the NRT rates are equal for both scenarios in the year 2010. Starting from 2011, the values in both scenarios are different since NRT rates increase at a different pace, and the "eco" scenario shows significantly slower growth of the amount of generated waste as the "base" 
scenario (Fig. 1) reaching the value which is by $15 \%$ lower than for the "base" scenario in the year 2030 (approximately 415 thsd. $t$ and 358 thsd. $t$ respectively). The growth rate of packaging waste in the "eco" scenario is slower than in the "base" scenario because the amount of packaging material per product unit is growing slower in the "eco" scenario than in the "base" scenario. This is explained by the fact that due to the faster growth of the NRT rate for packaging in the "eco" scenario, the price of raw materials for the packaging is rising faster and therefore a demand for the materials is increasing slower (albeit the demand still continues to increase following the current trend) than in the "base" scenario. It is cost effective for manufacturers in the "eco" scenario to reduce the amount of packaging materials used per product unit relative to the "base" scenario and this reduction can be achieved by implementing the product ecodesign. In the "eco" scenario the amount of packaging material is $0.17 \mathrm{~kg}$ per $1 \mathrm{~kg}$ of the packed product in 2030, which is $15 \%$ less than in the "base" case scenario and 6\% less than the European average in 2009 [7].

The hypothesis about decreasing packaging waste in the "eco" scenario is therefore confirmed by the model.

\section{B. Proportion of the population which is sorting waste}

The model assumes that if the rate of NRT for municipal waste disposal increases, the average costs of waste collection also increase, and this in turn should increase the fee of waste collection and the costs of the waste collection per capita, as well as motivate more people to engage in waste sorting. However, Figure 2 shows that in the "eco" scenario, the fraction of waste sorting population is basically the same as in the "base" scenario (being even slightly less in the "eco" scenario), respectively $77 \%$ and $76 \%$, which is an unexpected result.

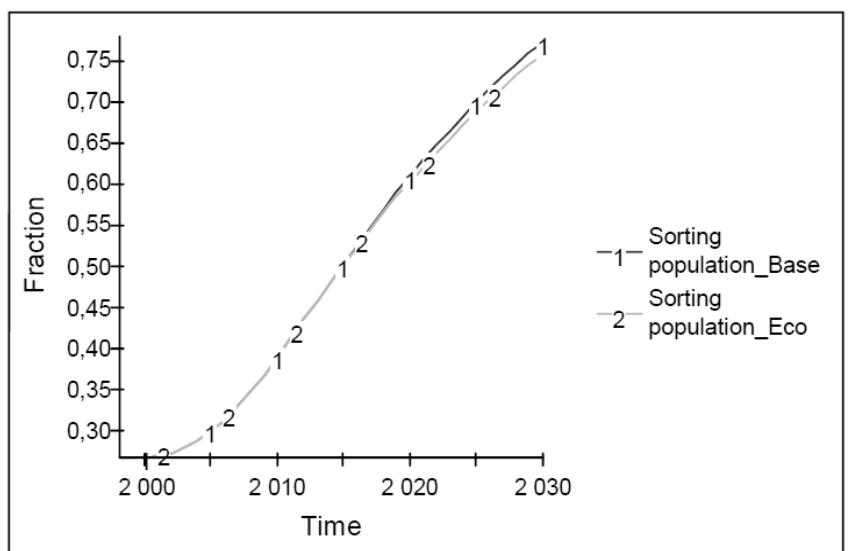

Fig. 2. Fractions of the population which is sorting waste in the "base"and in the "eco" scenarios.

The growth of the NRT rate for packaging reduces the amount of packaging waste generated as was discussed above. The waste collection payment per inhabitant depends not only on the waste collection fee per ton of the collected waste but also on the amount of waste generated. Therefore, the total waste collection payment per inhabitant in the "eco" scenario turns out to be lower than in the "base" scenario since the "slow-down" of the growth of the amount of generated packaging waste overruns an increase in the waste collection fee per ton of the collected waste. Namely, the NRT growth rate for municipal waste disposal is insufficient to offset the reduction of waste generation growth rate which is due to the NRT growth rate for packaging and the resulting ecodesign improvements.

A reduction in the waste sorting population is observed in the part of population which is motivated purely by economical considerations, i.e. waste collection costs, and the slower is growth of the waste collection costs the slower is the growth of number of the economically motivated sorters. The part of the population which consists of people who care about the environment and are motivated to sort waste because of the environmental impact, expressed as the landfill filling rate, is still increasing in both scenarios and is responsible for an overall increase of the sorting population fraction (Fig. 2).

Therefore, the hypothesis that a more rapid increase of NRT rates for packaging materials and municipal waste disposal in the "eco" scenario should lead to the faster growth of the sorting population fraction is not confirmed under the assumed NRT growth rates. A possible solution would be a more intensive increase of the NRT for municipal waste disposal.

\section{Proportion of the regenerated packaging waste}

The proportion of the regenerated packaging waste in the "base" and "eco" scenarios as well as with the regeneration target trendline are compared in Figure 3.

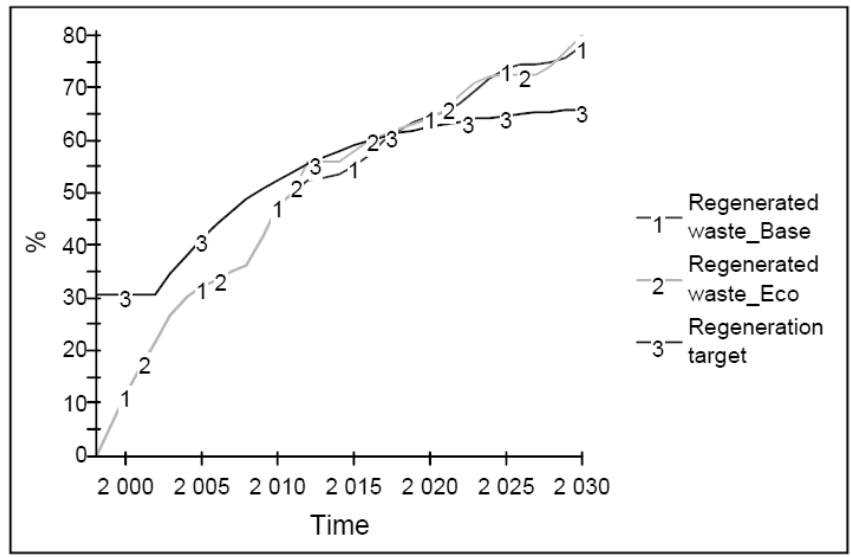

Fig. 3. Proportion of the regenerated packaging waste in the "base" and "eco" scenarios in comparison with the regeneration target.

As the graph shows, in both scenarios, the percentage of regenerated packaging waste is practically the same - in the "base" scenario almost $79 \%$ of the packaging waste is regenerated in the year 2030 and in the "eco" scenario this figure is slightly larger, i.e. $80 \%$ of the total packaging waste. Over the period of 2010-2017, the actual packaging waste regeneration levels are slightly below the projected regeneration targets. The simulation results show that the regeneration target in Latvia could be reached around 2017 in the "base" scenario, while in the "eco" scenario it could be around the year 2012. Over the period of 2020-2030, the actual regeneration rate may even exceed the regeneration targets if these targets are not changed substantially and will follow the existing trendline of increase. 
When comparing amounts of the regenerated packaging waste in 2030, it follows from calculations that approximately 330 thsd. t/year will be regenerated in the "base" scenario, and about 288 thsd. t/year in the "eco" scenario, since a lesser amount of the packaging waste is generated in the "eco" scenario.

The difference between proportions of the regenerated waste in the "base" and "eco" scenarios (Fig. 3) do not allow to firmly confirm the hypothesis about the increasing proportion of regenerated waste packaging in the "eco" scenario relative to the "base" scenario. However, while in the "eco" scenario the waste sorting population is slightly reduced relative to the figure in the "base" scenario and the total amount of the waste which is sorted out of the packaging waste stream is of a lower volume, the regeneration percentage is growing, because the incentive to recycle the waste which is being sorted out is created by a growth in the average market price of raw materials.

\section{Amount of the annually landfilled waste and the landfill filling rate}

The results of modeling the amount of annually landfilled packaging waste are shown in Figure 4.

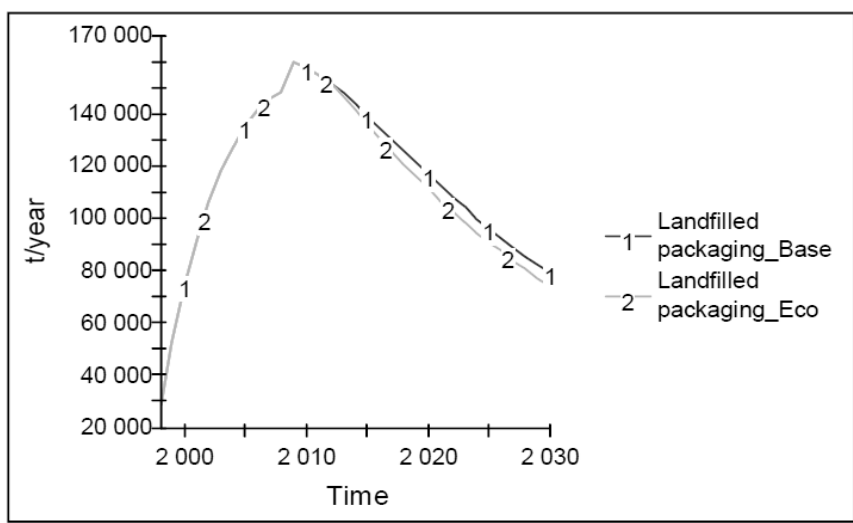

Fig. 4. Amount of the landfilled packaging waste in the "base" and "eco"scenarios.

In Figure 4 the modeling results show that the amount of packaging waste which is landfilled annually is decreasing during the period of 2010-2030. A similar trend is observed in both the "base" and the "eco" scenarios, with about $6 \%$ less packaging waste landfilled in the "eco" scenario in the year 2030.

The filling rates of the municipal waste landfill in the "base" and "eco" scenarios are shown in Figure 5.

Since the rate at which packaging waste is landfilled every year remains above zero (Fig. 4), the waste continues to pile up in the landfill sites (Fig. 5). In the "base" scenario, the rate of landfill filling is growing slightly faster than the "eco" scenario, reaching $88 \%$ of the accumulation capacity in year 2030.

The growth rate of landfill filling becomes slightly slower around the year 2020 but it still remains sufficiently fast and it could be anticipated that the capacity limit of the landfill could be reached soon after the year 2030. It was assumed in the model that during the year 1998 the fraction of filled landfill capacity is zero, and the calculations show how the actual remaining landfill capacity is occupied by the waste during the studied period.

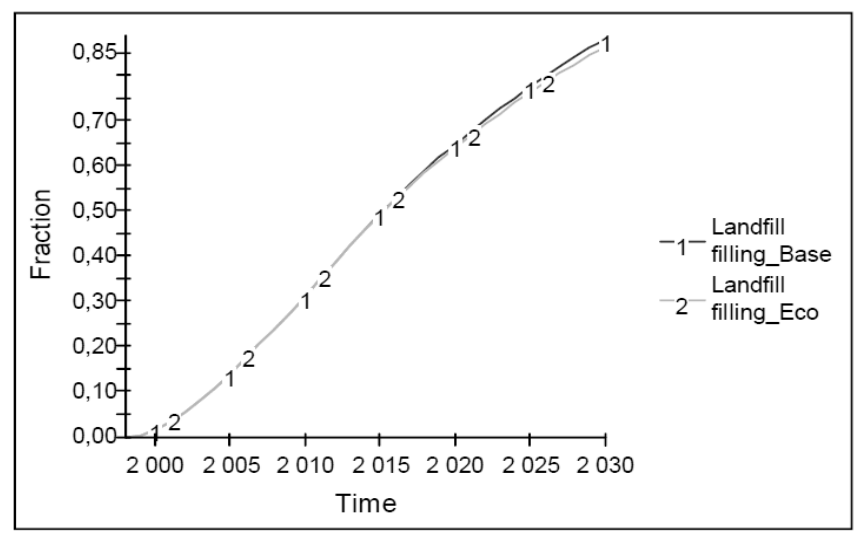

Fig. 5. Filling rates of landfill in the "base" and "eco" scenarios.

Despite the fact that in the "eco" scenario less packaging waste is generated, the amount which is landfilled is almost the same as in the "base" scenario (in the year 2030 about 80 thousand tons of the packaging waste will be landfilled annually in the "base" scenario and around 75 thousand tonnes in the "eco" scenario).

Therefore, the hypothesis that the amount of landfilled waste and landfill filling rate will decrease when increasing the NRT rate for packaging and for the municipal waste disposal is approved, but the difference between reduction of landfill filling rate in the "base" and "eco" scenarios is small. The increase of NRT rates reduce the total amount of generated packaging waste, but it also reduces a proportion of the waste sorting population in the "eco" scenario comparing to the "base" scenario as was discussed previously. The reduction of the sorting population reduces the amount of annually sorted packaging waste and therefore increasing the remaining fraction of un-sorted amount of the packaging waste which goes to landfill relative to the situation which would have been if the fraction of the sorting population would increase instead.

\section{E. Environmental impact of packaging materials}

When the amount of the packaging waste is increasing, the environmental impact caused by the packaging materials also increases. There are two solutions to reduce environmental impact - the first solution is to use less packaging, but this trend can be changed only over a long period of time. Another solution that can be implemented faster is to change the packaging material composition by increasing the proportion of materials that cause less environmental impact.

One of the ecodesign principles is to select those materials that have the smallest environmental impact throughout their life cycle, if possible. Material impact on the environment of the production, construction, transportation and end-of-life stages can be characterized by a quantitative environmental impact analysis method such as the "Eco-indicator 99" method developed for ecodesign purposes [8]. This method is used in the calculations to identify the environmental impact when using different packaging materials. 
Impact on the environment from materials is described by ecoindicator points $(\mathrm{Pt})$. The ecoindicator points allow to make a relative comparison between the environmental impact among various product design solutions, materials and processes. The scale is chosen so that $1 \mathrm{Pt}$ would reflect an average impact on the environment by one inhabitant of Europe per year [8].

Figure 6 compares the total impact of all packaging materials on the environment in the "base" and "eco" scenarios.

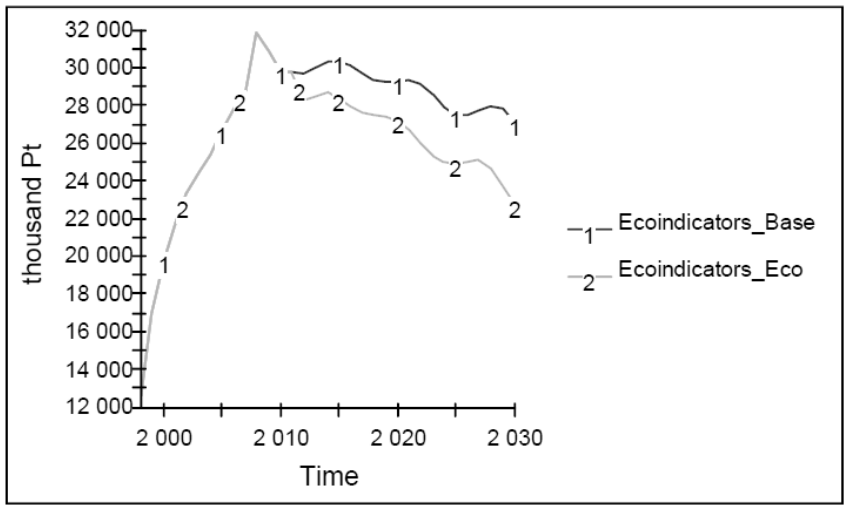

Fig. 6. Ecoindicators of packaging materials in the "base" and "eco" scenarios.

The impact on the environment of packaging materials is about $15 \%$ less in the "eco" scenario than in the "base" scenario during the period from 2015 to 2030. Therefore, the previously proposed hypothesis that the environmental impact in the "eco" scenario should be lower than in the "base" scenario is correct. Ecoindicators of the environmental impact of packaging materials are calculated by using the data on generated and regenerated amounts of packaging materials obtained from the model. Regeneration percentages in both scenarios are similar, but the "eco" scenario generates less packaging, which provides a reduction in the total environmental impact of the packaging materials.

The possible changes in the composition of the waste containing such materials as glass, paper, plastic, wood and metal are not modeled and there is no analysis how the substitution of one material with another could change the environmental impact. However, the effect of the growth of NRT rates for packaging materials in the scenarios show that the tax changes have a major impact on the generated amount of packaging waste. Higher rates of NRT corresponding to the environmental impact caused by materials would motivate producers and retailers to implement ecodesign and use materials which are less harmful for the environment whenever possible, as well as increase the use of recycled materials and reduce the amount of packaging materials per product unit.

\section{$F$. Changes required for development of effective policy}

The previously described analysis of both scenarios shows that in the case of the "eco" scenario, three of the five hypotheses were confirmed. In the "eco" scenario, the expected result is not achieved regarding the growth of the proportion of the population engaged in the packaging waste sorting. The effective implementation of ecodesign policy, however, should help in achieving the desired result for this system's variable as well, and therefore the "eco-2" scenario was created in addition to the two scenarios described previously.

The rate of NRT for municipal waste disposal was increased to an even greater extent than in the "eco" scenario in order to achieve an increase in the proportion of sorting population. Namely, in the "eco-2" scenario, the NRT rate for municipal waste disposal is increased 5 times faster than in the "eco" scenario, starting from the year 2013. The values of the rate of NRT in the "eco-2" scenario are almost four times larger in 2030 compared to the rate in the "base" scenario, i.e. reaching approximately $50 \mathrm{LVL} / \mathrm{t}$ in the "eco-2" scenario.

Figure 7 shows the fraction of the population engaged in packaging waste in all three scenarios. In the "eco-2" scenario the proportion of the sorting population reaches $78 \%$ which is by $1 \%$ more than in the "base" scenario.

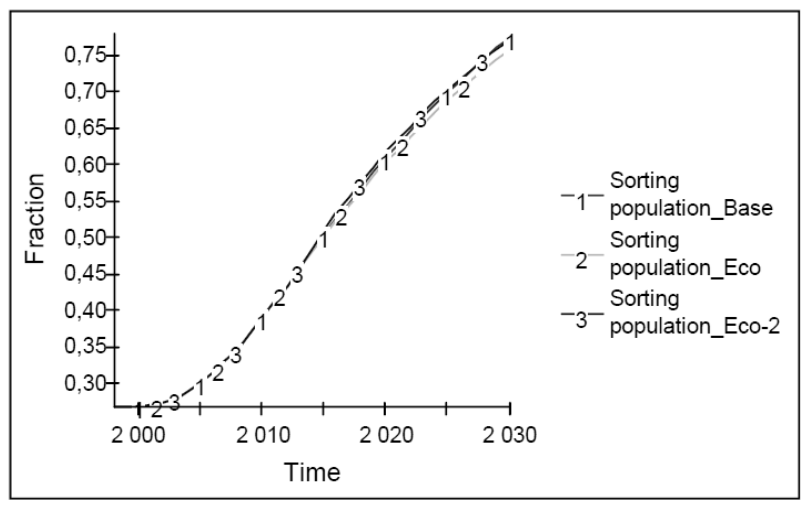

Fig. 7. Fractions of the waste sorting population in all three scenarios.

When the proportion of the waste sorting population increases relative to the "eco" scenario, a more profound reduction of the amount of waste being disposed in landfills annually can be achieved (see Fig. 8).

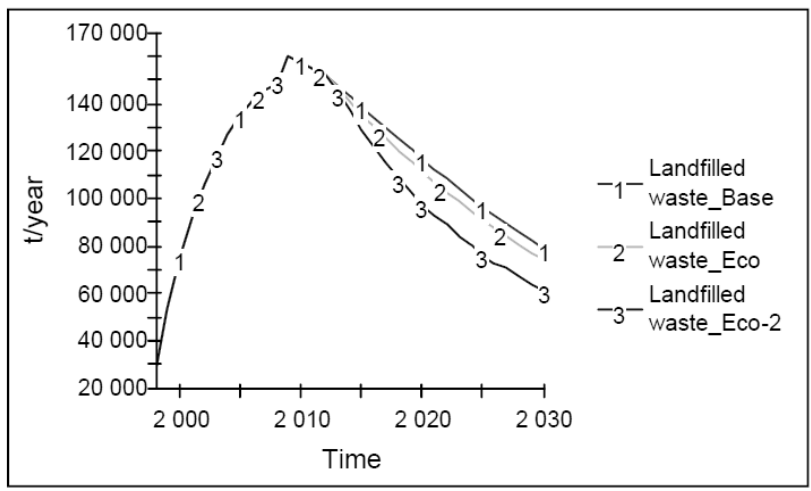

Fig. 8. Amount of the landfilled packaging waste per year in all three scenarios.

As the graph in Figure 8 shows, in the "eco-2" scenario in year 2030 the amount of landfilled packaging waste is $29 \%$ less than in the "base" scenario and $22 \%$ less than in the "eco" scenario. The landfill filling rates in the "eco-2" scenario are shown in Figure 9. 


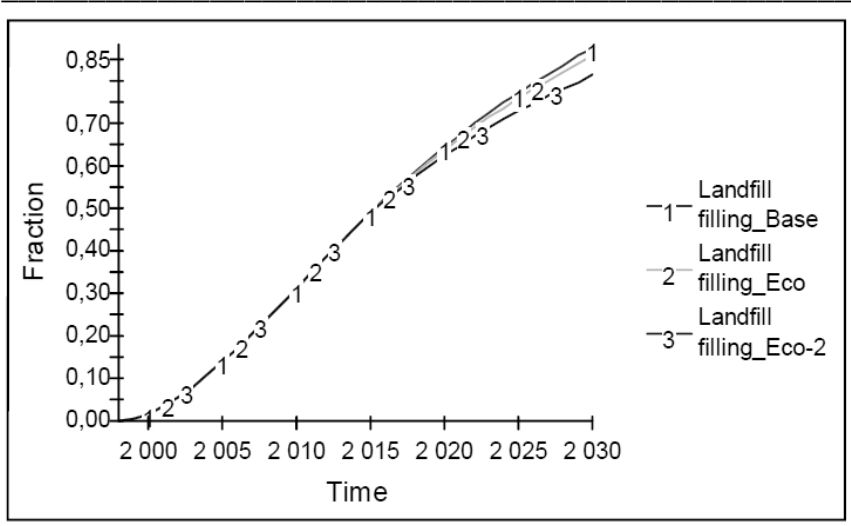

Fig. 9. The rates of landfill filling in all three scenarios.

Figure 9 shows that after the year 2020 the growth rate of landfill filling in the "eco-2" scenario slows down more noticeable than in the "eco" scenario, and the filling level of landfills in 2030 is $83 \%$ which is by approximately 5\% less than in the "base" and "eco" scenarios. The slower growth of landfill filling rate in the "eco-2" scenario can be explained by the higher proportion of the sorting population and lower rates of waste generation, than in the "base" and "eco-2" scenarios, which is shown in Figure 10.

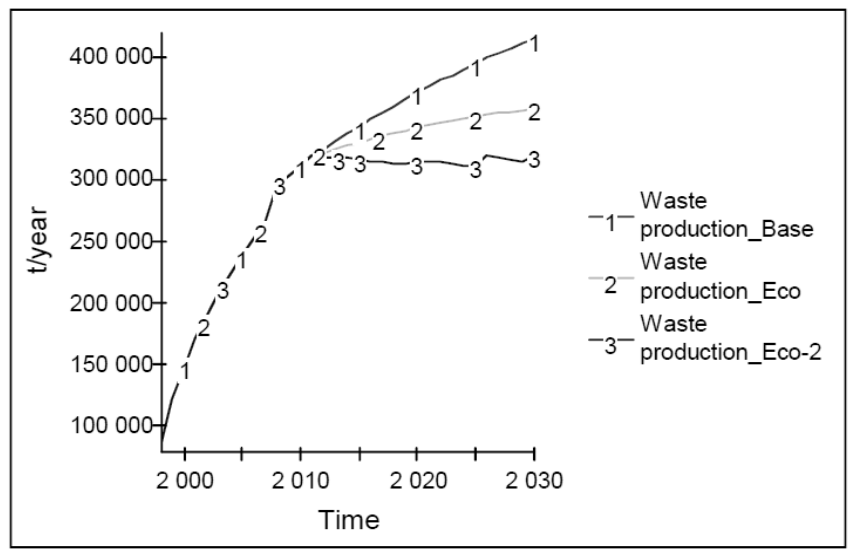

Fig. 10. Amounts of the generated packaging waste in all three scenarios.

Increase of the NRT rate for packaging rate by $29 \%$ by the year 2030 in the "eco" scenario caused a reduction in the amount of packaging per product unit by $15 \%$ in comparison with the "base" scenario, but when the NRT rate was increased by $100 \%$ in the year 2030 in the "eco-2" scenario comparing to the "base" scenario, the amount of packaging per product unit is decreased by $25 \%$, compared with the "base" scenario. Therefore, it can be concluded that, if the rate of NRT for packaging grows faster, proportionally less effect is achieved - in the "eco" scenario the effect, expressed as the ratio between achieved relative reduction of the packaging per product unit and the relative increase of the NRT rate for the packaging material, is two times higher than in the "eco-2" scenario. In the "eco-2" scenario the NRT rate for packaging in 2030 reaches $0,84 \mathrm{LVL} / \mathrm{kg}$, which is 2 times higher than in the same year for the "base" scenario and 3.2 times higher than the weighted average rate in 2010 , i.e. $0.26 \mathrm{LVL} / \mathrm{kg}$.
In the "eco-2" scenario, decrease of the growth rate of packaging per product unit allows to achieve stabilization of the yearly generated amount of packaging waste at the level of 2011 , i.e. 320 thsd. tons per year in the year 2030, as can be seen from Figure 10. Figure 10 also shows that the volume of the generated packaging waste even slightly decreases over the period of $2010-2025$.

Results of the "eco-2" scenario show that the NRT rate for packaging can affect the packaging waste system of Latvia and it is possible to influence the growth rate of the amount of packaging per product unit, but this can be achieved if the tax increase is at least two times faster than in the "base" scenario.

\section{CONCLUSIONS}

The main conclusions which could be made based on the results of research are the following:

1. If the natural resource taxes on the materials used in packaging and on the disposed municipal waste are used as a policy instruments, and the growth of those factors is affected by the amount of annually generated packaging waste and the extent of landfill filling in the model, the yearly amounts of generated and landfilled waste can be decreased. The taxes increase the cost of packaging materials for producers and the fee for waste collection for inhabitants, thereby reducing the growth rate of waste volume by circa $33 \%$ and increasing waste sorting population from approximately $40 \%$ to $77 \%$ in the year 2010 relative to the year 2030 for the "base" or reference scenario. In the time period of $2010-2030$, an annual amount of landfilled packaging waste decreases by $50 \%$ in the "base" scenario but nevertheless, $88 \%$ of the available existing landfill capacity will be filled up until 2030 even with reduced rate of the filling.

2. Changes which are achieved by year 2030 in the "eco" scenario case relative to the "base" scenario are as follow:

a) The annual amount of generated packaging waste is reduced by $14 \%$,

$b$ ) The annual amount of landfilled waste is reduced by $6 \%$,

c) Impact of packaging materials on environment is reduced approximately by $15 \%$.

3. The hypothesis that by increasing the rate of NRT more substantially, the proportion of the waste sorting population will increase, compared with the "base" scenario, is not confirmed in the "eco" scenario. In the "eco" scenario proportion of the waste sorting population is even slightly less than in the "base" scenario. In this case, system dynamics model shows that the result may be unexpected, due to existing interrelations between elements of the system and feedback loops. In the "eco" scenario the growth rate of NRT for municipal waste disposal is insufficient to offset the reduction of the waste generation growth rate which reduces a motivation for the sorting.

4. The NRT for packaging materials can affect the packaging system of Latvia and it is possible to effectively influence the growth rate of the packaging per 
product unit, but this can be achieved if two times faster tax increase than in the "base" scenario is provided. In the "eco-2" scenario the achieved level of packaging per product unit provides that the packaging waste generated in 2030 remains at the level of 2011 (320 thsd. t/year).

5. Raising the NRT rates for packaging and for municipal waste disposal by even larger extent than in the "eco" scenario in the "eco-2" scenario, ensures that the landfilled amount of packaging waste is by $29 \%$ lower than in the "base" scenario and by $22 \%$ lower than in the "eco" scenario in year 2030.

6. The existing legislative instruments can be used to create an effective policy for ecodesign implementation and stop waste accumulation in landfills, but both NRT rates, i.e. for the packaging materials and the waste disposal should be even higher than in the "eco-2" scenario.

\section{ACKNOWLEDGMENTS}

The study presented in this paper was possible due to the project "System thinking integration in environmental policy" (Nr. W7579) which was financed by European Economic Area and Norwegian Government Financial Instrument and the Republic of Latvia.

\section{REFERENCES}

1. Statistical report of generated packaging and amount of recovered resources in Latvia according to resolution 2005/270/EKby European Commision. Riga: LISC, 2008.

2. On consumption patterns for inhabitants in cities of Valmiera $(L V)$ and Viljandi (EE). Report on case study. Baltic Environmental Forum, 2006.

3. Regulations No 65 issued by the Cabinet of Ministers: Regulations Regarding Recovery Percentage Volume (Proportion) and Time Periods of All Packaging Waste, Procedures for the Registration and Submission of Reports and Model Forms Thereof, Requirements Which a Commercial Company Must Fulfil in Order for It to Be Registered as a Packaging Manager, Examples of the Application of the Packaging Definition Criteria and Exceptions in Relation to the Heavy Metal Content in Packaging. Latvijas Vestnesis, No 15, 16 January 2007.

4. Vizayakumar K., Environmental policy analysis: System dynamics approach (Chapter 20), V.K. Agnihotri, Public policy analysis and design, Concept Publishing Company: New Dehli, pp. 311-329, 1995.

5. Saleh M., Oliva R., Kampmann C.E. \& Davidsen P.I., A comprehensive analytical approach for policy analysis of system dynamics models, European Journal of Operational Research, Volume 203, pp. 673-683, 2010.

6. Law issued by the Republic of Latvia: Law of Nature Resource Tax. Latvijas Vestnesis, No 100, 30 June 2009.

7. Packaging Trends for Fast Moving Consumer Goods in Selected European Countries. Part 1: First data collection. Public report. EUROPEN (Belgium) and STFI-Packforsk AB (Sweden), 2009.

8. The Eco-indicator 99. Manual for designers. Ministry of Housing, Spatial Planning and the Environment, The Netherlands, 2000.

Alise Berzina, Mg.sc.ing., Researcher

Institute of Energy Systems and Environment, Riga Technical University Address: Kronvalda blvd. 1, LV 1010, Riga, Latvia

Phone: +371 67089923, Fax: +37167089908

E-mail: alise.berzina@rtu.lv

Elina Dace, Mg.sc.ing., Researcher

Institute of Energy Systems and Environment, Riga Technical University

Address: Kronvalda blvd. 1, LV 1010, Riga, Latvia

Phone: +371 67089923, Fax: +37167089908

E-mail: elina.dace@rtu.lv

Gatis Bazbauers, Dr.sc.ing., Professor

Institute of Energy Systems and Environment, Riga Technical University

Adress: Kronvalda boulv.1, LV-1010, Riga, Latvia

Phone.: +371 7089908, Fax: +371 7089908

e-mail: bazbauer@latnet.lv

Alise Bērziṇa, Elīna Dāce, Gatis Bažbauers. Ekodizaina ieviešanas un risinājumu analīze iepakojuma atkritumu sistēmai ar sistēmdinamikas modelēšanas palīdzību

Šobrīd viena no aktuālākajām vides piesārņojuma problēmām ir aizvien pieaugošais atkritumu daudzums, kas nonāk poligonos. Iepakojuma atkritumi sastāda lielu īpatsvaru- apmēram $20 \%$ no kopējiem sadzīves atkritumiem. Šajā darbā izklāstîti izpētes par Latvijas iepakojuma sistēmu rezultāti. Galvenā uzmanība tiek pievērsta tam, kā ar politikas instrumentu palīdzību ir iespējams veicināt ekodizaina ieviešanu un materiālu izmantošanas efektivitātes paaugstināšanos, tādējādi samazinot iepakojuma atkritumu pieauguma tempu. Pētījumā izmantotā metode ir sistēmdinamikas modelēšana. Modelis veidots laika posmam no 1998. līdz 2030. gadam, lai būtu iespējams imitēt pagātnes datus un, ievērojot faktoru mijiedarbību, kā arī mainot ar atkritumu apsaimniekošanas politiku ietekmējamo faktoru vērtības, prognozēt dažādus nākotnes attīstības scenārijus. Galvenie sistēmas elementi, kas tiek analizēti darbā un salīdzināti savā starpā dažādu scenāriju gadījumos, ir: ikgadēji radītais iepakojuma atkritumu daudzums, atkritumus šķirojošo iedzīvotāju īpatsvars, reǵenerēto atkritumu īpatsvars, ikgadēji noglabāto atkritumu daudzums un iepakojuma materiālu ietekme uz vidi. Izpētes mērksis ir analizēt, kāda politika būtu efektīva un lautu samazināt iepakojuma ražošanai nepieciešamo primāro resursu patēriņu un radītā izlietotā iepakojuma apjomu, tāpēc bez „,bāzes scenārija” tiek izstrādāts ar̄̄ ,eko scenārijs”. Ar esošo likumdošanas instrumentu palīdzību ir iespējams izveidot efektīvu ekodizaina ieviešanas politiku, taču abu dabas resursu nodokḷa (DRN) likmes ir jānosaka krietni augstākas nekā eko scenārijā. Ar Dabas resursu nodokḷa palīdzību ir iespējams efektīvi regulēt iepakojuma uz produkta vienību pieauguma tempu un tādējādi panākt, ka ikgadēji radītais izlietotā iepakojuma daudzums līdz 2030.gadam paliek 2011.gada līmenī (320 tūkst.tonnu gadā).

\footnotetext{
Алисе Берзиня, Елина Даце, Гатис Бажбауер. Анализ введения экодизайна и решений для системы упаковочных отходов с помощью моделирования динамики систем

Одна из наиболее важных экологических проблем загрязнения в Латвии это увеличение количества отходов, поступающих на полигоны. Упаковочные отходы занимают большую часть, приблизительно $20 \%$, от общего объема бытовых отходов. В данной работе рассматриваются результаты исследования системы упаковки в Латвии. Особое внимание уделяется политическим механизмам, которые способствуют реализации экодизайна и эффективности использования материалов, таким образом, уменьшая прирост упаковочных отходов. В исследовании, используемый метод анализа системы упаковочных отходов, называется моделирование динамики систем. Модель была сделана для периода времени с 1998 года до 2030 года, чтобы иметь возможность эмитировать прошлые данные и прогнозировать различные сценарии развития на будущее, учитывая взаимодействие различных факторов, а также меняя значения факторов, связанных с политикой управления отходами. Основные элементы системы, которые анализируются и сравниваются между собой в различных сценариях, следующие: ежегодный объём упаковочных отходов, доля населения, сортирующая отходы, доля переработанных отходов, ежегодное количество утилизируемых отходов и воздействие упаковочного материала на окружающую среду. Цель исследования - проанализировать, какая политика будет более эффективной и будет давать возможность уменьшить потребление первичных ресурсов для производства упаковки, поэтому наряду с «базовым сценарием» разрабатывается «эко сценарий». Основной вывод состоит в том, что существующие законодательные инструменты могут быть использованы для создания эффективной политики введения экодизайна, но обе ставки налога на природные ресурсы должны быть значительно выше, чем в эко-сценарии. С помощью налога на природные ресурсы можно эффективно регулировать темпы роста упаковки на единицу продукции и, следовательно, добиться того, чтобы количество отходов упаковки в 2030 году осталось на уровне 2011 года (320 000 т/год).
} 